Franciszek Adamski*

Kraków

\title{
Pedagogika chrześcijańska pedagogiką personalistyczną
}

\section{Niektóre wspólczesne nurty myślenia o wychowaniu}

Na polskim forum publicznym już od 20 lat ujawniane są kontrowersje towarzyszące toczonym w środowiskach naukowych, a także i politycznych, względnie światopoglądowych, dyskusjom wokół szkoły i wychowania. Dylematy, przed jakimi stają teoretycy wychowania i które nie są obce nauczycielom-wychowawcom, a niejednokrotnie i rodzicom, można sprowadzić do następujących pytań:

- czy wskazywać młodemu człowiekowi określony, nadprzyrodzony, czy wyłącznie ziemski sens życia i proponować mniej lub bardziej wymagające wzorce jego realizacji;

- czy też poprzez stawianie określonych zadań, odwoływanie się do potrzeb społeczeństwa, kształtować zainteresowania, postawy, uczyć samodyscypliny i liczenia się z oczekiwaniami i prawami innych;

- czy preferować, jako ideał wychowania, przede wszystkim człowieka całkowicie ,wyzwolonego”, rezygnując z wartości, rygorów i wymagań tradycyjnie uznawanych za niezbędne w procesie prawidłowego wychowania, które powinno być pozostawione własnemu biegowi i realizować się w codziennych doświadczeniach wychowanka?

Od tych i innych jeszcze dylematów prowadzi - jak wiadomo - droga do filozoficznego myślenia o wychowaniu, wyrażającego się w określonych

* Prof. dr hab. Franciszek Adamski - emerytowany profesor Uniwersytetu Jagiellońskiego w Krakowie. 
stanowiskach teoretycznych czy wręcz usystematyzowanych nurtach filozoficznych, z których każdy ubiega się o największą liczbę zwolenników. Do bardziej znanych zalicza się: nurt laicki, radykalno-emancypacyjny, technologiczno-funkcjonalny, pedagogikę steinerowską, humanistyczną, antypedagogikę i pedagogikę personalistyczną, najczęściej utożsamianą z chrześcijańska.

Jak wiadomo, w nurcie laickim celem wychowania jest ukształtowanie postaw racjonalnych. Obowiązuje tu przeświadczenie głoszące, że nie ma spraw-rzeczy niewyjaśnialnych: zdolności poznawcze intelektu ludzkiego są w zasadzie nieograniczone, a doskonaląc narzędzia poznania, będzie on w stanie wyjaśnić to, co dziś jeszcze stanowi dlań tajemnicę. Prawda o świecie ustawicznie się zmienia - bowiem sam świat się zmienia. Nie ma zatem niezmiennych, absolutnych zasad. Człowiek jako cząstka świata jest równocześnie poddany w swym myśleniu i zachowaniu wpływom otaczającej go rzeczywistości. Jako twórca rzeczywistości kulturowej jest jednocześnie w swej naturze jej wytworem. Całym swym jestestwem wypełnia się w granicach doświadczalnego, poznawalnego świata.

W nurcie pedagogiki radykalno-emancypacyjnej głoszona jest teza akcentująca przymiot doskonałości i wolności jestestwa ludzkiego od chwili jego urodzenia. Niemniej jednak każdy człowiek jest włączony w świat rzeczy i myśli ograniczającej jego swobodny rozwój. Zatem wyzwalanie się z tych krępujących więzów i uwarunkowań staje się koniecznością a zarazem prawem człowieka. To wyzwalanie wyrazi się poprzez formułowanie własnych celów i norm, domaganie się uzasadnień dla tego, co ma mieć charakter obowiązujący zarówno jednostkę, jak i całe społeczeństwo. Na czoło wysuwane są przeto słowa, względnie hasła-klucze: wolność, tolerancja, dialog. Stanowią one w praktyce podstawę dla subiektywizmu i relatywizmu.

Nurt technologiczno-funkcjonalny traktuje wychowanie jako narzędzie realizowania celów społecznych państwa. Proponuje zatem koncentrowanie się w wychowaniu na rozwoju zainteresowań i predyspozycji intelektualnych wychowanka służących realizacji oczekiwań społeczeństwa. Proces myślenia jest postrzegany jako instrument pojęciowej organizacji rzeczywistości. Podstawowym zadaniem wychowania-nauczania jest nabywanie kompetencji w celu funkcjonalnego kształtowania rzeczywistości ludzkiego życia, zarówno w jego wymiarze jednostkowym, jak i społecznym. Wychowanie ma tu zatem pełnić funkcję służebną na rzecz społeczeństwa i jemu winno być podporządkowane.

Pedagogika steinerowska opiera się na antropozofii, stanowiącej mieszaninę idei gnostyczno-manichejsko-indyjsko-chrześcijańskich, głoszącej tożsamość natury Boskiej i ludzkiej, immanencję Boga wobec świata, poza 
którym nie istnieje. Człowiek z natury jest dobry, ale żyje w rzeczywistości przenikniętej złem stanowiącym zagrożenie $\mathrm{w}$ jego prawidłowym rozwoju. Pedagogika nie oznacza w tej sytuacji nic innego, jak terapię duchowo-moralną, w której czynnik religijny odgrywa zasadniczą rolę. Wychowanie religijno-moralne, na które kładzie się tu szczególny nacisk, zmierza ku ukształtowaniu ogólnej „pobożności” rozumianej jako postawa czci wobec mądrości, piękna i dobra, które są udziałem człowieka i wypełniają otaczający go świat.

Zauważmy, że - aczkolwiek osadzona na takich założeniach - szkoła waldorfska, będąc wolnym zrzeszeniem opartym na współpracy rodziców, nauczycieli i uczniów, pozbawiona struktury hierarchicznej a odwołująca się do czynnika religijnego, jest z gruntu obca chrześcijaństwu.

Nurt pedagogiki humanistycznej nawiązuje do racjonalizmu krytycznego K. Poppera. Na polskim gruncie znalazł szersze rozwiniecie w twórczości powojennej B. Suchodolskiego. Zasadnicze idee tego nurtu to otwartość na świat i człowieka, który - jako jego szczególny element - jest w nim całkowicie zanurzony, poddany jego determinacjom, a zarazem świadomy tych determinacji, potrafi z nich korzystać w celu zmiany tego świata, to znaczy twórczego przekształcenia świata odczłowieczonego w świat ludzki. Jednakże jest on niezdolny dochodzić właściwego kierunku możliwych przemian: refleksja nad wyborem kierunku przemian jest w każdym przypadku uwarunkowana kulturowo, religijnie i ekonomicznie.

Świadomy swego bytowania, aczkolwiek niezdolny pojąć jego istoty i sensu, sam - skoro „nie ma nic ponad nami” - musi odpowiadać na pytania ostateczne towarzyszące mu przez całe życie. Czyni to wysiłkiem własnego umysłu, podejmowanym w dialogu z innymi ludźmi, i to nie tylko tymi, którzy żyją współcześnie, ale także tymi, którzy już odeszli, pozostawiając po sobie twórczy wkład w dzieło kultury.

Zadaniem pedagogiki jest przygotowanie człowieka do współżycia w konkretnych stosunkach międzyludzkich przez nauczanie ludzi określonych ról społecznych. Nie jest nim natomiast przystosowanie ludzi do oczekiwań społeczeństwa. Jednostka ludzka ma bowiem wartość samoistna, a - żyjąc $\mathrm{w}$ społeczności - wspólnie $\mathrm{z}$ innymi poszukuje najlepszych sposobów rozwiazywania swych problemów egzystencjalnych, bez odnoszenia się do świata rzeczywistości pozaziemskiej - chyba że rozumianej w postaci dzieł kultury, które tworząc człowiek przekracza skończoność swego istnienia. Jako element natury, człowiek wyrasta ponad nią, transcenduje ją - wychodząc w świat kultury, względnie tworząc świat kultury. I to właśnie stanowi istotę i jedyny sposób wyrażania przez człowieka jego duchowości. Pedagogika humanistyczna, zbudowana na powyższych założeniach ma wyłącznie antropocentryczny charakter i to ją odróżnia od nurtu personalistycznego. 
Nurt antypedagogiki pojawił się pod koniec XX wieku jako refleksja z niespełnionych oczekiwań oddziaływań wychowawczych stosowanych przez różne szkoły myślenia o wychowaniu. Zdaniem niektórych teoretyków wychowania, jakakolwiek pedagogika powoduje okaleczenie wychowanka, bowiem nie przyjmuje go takim, jakim jest, ale dąży do jego wewnętrznej przemiany i udoskonalenia. Dzieje się to natomiast kosztem pozbawienia wychowanka jego autonomii, owszem, mniej czy bardziej ukrytego zniewolenia. Należy zatem znieść wszelkie formy i sposoby wychowania. Właściwe bowiem pojmowanie wychowania uwzględnia najbardziej istotny element, którym jest stwarzanie warunków spontanicznego, niczym nieograniczonego rozwoju młodego człowieka. W praktyce oznacza to tworzenie szkół alternatywnych, zakładających bezstresowość, pełną wolność i swobodny rozwój samowychowującego się wychowanka. Zbędne są w tym świetle, wychodzące poza potrzebę zniesienia wszelkich form wychowania i towarzyszących im zasad, bezowocne dyskursy o wychowaniu.

\section{Antropologiczny fundament pedagogiki chrześcijańskiej - personalistycznej}

Na zgoła innym, aniżeli przywołane wyżej nurty pedagogiczne, antropologicznym fundamencie zbudowana jest pedagogika personalistyczna w jej wersji chrześcijańskiej - pedagogika perennis. Kamieniem węgielnym owego fundamentu jest biblijna wizja człowieka, ,stworzonego na obraz i podobieństwo Boże", dotkniętego-zranionego grzechem pierworodnym (co ma swe głębokie konsekwencje w jego procesie wychowania i moralnych zachowaniach na przestrzeni całego życia), ale z niewypowiedzianej miłości Stwórcy odkupionego zbawczą męką Chrystusa, który na drodze pracy nad sobą oraz dzięki pomocy „Z góry”, jest w stanie upodobnić się do doskonałości swego Zbawiciela jako modelu wychowania.

Ów fundament „,nadbudowany” był przez wieki dzięki ustawicznie dręczącemu myślicieli (i nie tylko myślicieli) pytaniu o istotę-naturę człowieka, cel i sens jego życia oraz ostateczne jego przeznaczenie. Każdy z najbardziej znanych myślicieli wnosił jakiś swój wkład do postępującej przez wieki budowy interesującej nas tu filozoficznej wizji człowieka, której na przełomie IV i V wieku św. Augustyn nadał jednoznaczny wymiar personalistyczny. Jego antropologia głosi, że ani ciało, ani dusza nie są pełnym człowiekiem: dopiero oba te elementy razem zespolone składają się na osobę ludzką. Jednakże klasyczną filozoficzną definicję osoby konstruuje dopiero Boecjusz w około 100 lat po Augustynie. Określa on osobę mianem ,indywidualnej substancji rozumnej natury". Z definicji tej wynika, że osobą jest jestestwo 
bytowo niepodzielne, posiadające atrybuty rozumu i woli, dzięki którym posiada świadomość swego psychicznego ,ja”.

Ta definicja osoby wystarczała filozofom wczesnego średniowiecza i żaden ze znanych myślicieli przez następne stulecia nie podjął ani jej pogłębiającej interpretacji, ani merytorycznego uzupełnienia. Refleksja nad człowiekiem wielu ówczesnych filozofów i teologów była uprawiana w nurcie myślenia św. Augustyna i do końca XII wieku w zasadzie nie wychodziła poza jego granice.

Dopiero zdecydowanie nowe elementy w owej refleksji pojawiają się w antropologii św. Tomasza z Akwinu (†1247), który w swej hierarchicznej wizji rzeczywistości ziemskiej przyznaje człowiekowi miejsce na przecięciu sfery materii i ducha, życia biologicznego i umysłowego. Ludzka osoba to compositum duszy i ciała, w ramach którego dusza jest czynnikiem organizującym i formującym materię. Istotę osoby konstytuują trzy elementy: samoistność, własny akt istnienia, rozumność i indywidualność. Osoba jest tym, co przyroda posiada najdoskonalszego.

Na podłożu nadal przez wieki następne snutych refleksji nad człowiekiem w jego osobowym wymiarze (B. Pascal, R. Kartezjusz, S. Kierkegaard, M. Scheler, G. Marcel, J. Maritain, E. Mounier, K. Wojtyła) filozoficzna myśl XX-wieczna dokonuje zwieńczenia owej konstrukcji wizji człowieka jako osoby ludzkiej wyposażonej w określone cechy-przymioty, z której wynikają jej niezbywalne prawa, a także i obowiązki. Nie wolno nie zauważyć, że nasilenie w owym dziele „zwieńczenia” zostało spowodowane dochodzącą do głosu antychrześcijańską, antypersonalistyczną wizją człowieka (G. W. F. Hegel, F. Nietzsche, K. Marks, J. P. Sartre, M. Marleu-Ponty), na której następnie zbudowano społeczno-ustrojowy system państwa (hitleryzm, faszyzm, a zwłaszcza komunizm) i będący na jego usługach system edukacji i wychowania. Jak wiadomo, budując ów system, na szeroką skalę wyłączono z pola widzenia samego człowieka, uprzedmiotowiono go i zinstrumentalizowano samego nauczyciela, a przede wszystkim proces i instytucje wychowania - ukierunkowując szkołę i nadając jej zaprogramowany ideologiczny charakter i wymiar.

To bolesne i ciaggle dające o sobie znać doświadczenie nasuwa nieodpartą konieczność zwrócenia się w stronę pedagogiki zbudowanej na personalistycznej wizji człowieka-osoby jako podmiotu wychowania wraz z jej niezbywalnymi prawami i przymiotami, wśród których prawo do prawdy o sobie i świecie wybija się na naczelne miejsce. Osoba jest tu pojmowana jako rzeczywistość materialno-duchowa, stanowiąca w pewnym sensie odrębny świat (mikrokosmos) i jako taka nie może stanowić produktu ewolucji świata materialnego. Ona panuje nad światem materialnym, uniezależnia się od niego i posługuje się nim jako środkiem do osiągania własnego celu, 
zarówno w wymiarze przyrodzonym, jak i nadprzyrodzonym. Będąc substancją natury rozumnej, stanowi byt samoistny, w którym krzyżują się dwie rzeczywistości - materialna i duchowa - składając się na jedność. Osoba przeto nie utożsamia się z duszą ale z całością złożoną z ciała i duszy. Jako taka jest ona przedmiotem działania rozumnego i wolnego. Oznacza to, że jest bytem z istoty swej zdolnym do poznania umysłowego (także poznania Bytu Najwyższego), do podporzadkowania sobie ziemskiej rzeczywistości, odkrywania w niej ładu oraz stworzenia ładu estetycznego i moralnego - i to zarówno w sobie, jak i w otaczającej go rzeczywistości.

Rozważana z punktu widzenia psychologicznego osoba ujawnia swa cechę świadomości i potencjalności własnej jaźni, jej kształtowania się i rozwoju poprzez poznawanie i działanie. Poznawanie to może ustawicznie pogłębiać, działanie doskonalić, a świadomość rozwijać, kształtować - i tą drogą dopełniać swą osobowość. Jest przeto zwartą, odrębną i niepowtarzalną rzeczywistością psychiczną, świadomą siebie, swych przymiotów i praw. Wśród cech-przymiotów osoby personalizm dostrzega przede wszystkim jej duchowość. Stanowi ona swoiste wyzwanie dla osoby: wyzwanie do ciagłego trudu samodoskonalenia się, upodobniania się do doskonałości Stwórcy.

Nieśmiertelność jest następną cechą osoby. Dążenie do doskonałości jest obowiązkiem moralnym wynikającym z istoty człowieczeństwa, wynikającym z jego wnętrza - popychającego go do samodoskonalenia niemającego czasowych granic. Jest ono wynikiem świadomości potrzeby dążenia do doskonałego trwania przekraczającego bariery czasu. Jest wreszcie obowiązkiem moralnym niedanym z zewnątrz, lecz wyłaniającym się z wnętrza podmiotu.

Integralność osoby oznacza tu, że człowiek jest całością a nie częścią czegoś - i jest całością spójną, kompletną: a jeśli tak, to od siebie samego otrzymuje zadania, obowiązki i uprawnienia, przede wszystkim zaś wartość najwyższą w świecie bytów stworzonych i wolność.

I tu wyłania się problem natury najbardziej pedagogicznej, a mianowicie: na ile jest się osobą a staje się osobowością? Na tym bowiem zasadza się proces wychowania, aby stopniowo dochodzić do własnej doskonałości, umiejętnie kształtować proces własnego doskonalenia, poprzez który stajemy się dojrzałą osobowością. I z istoty ludzkiej wynika to, że chce zawsze być w pełni sobą - formować się i na swój sposób doskonalić. Nigdy nie może powiedzieć o sobie, że jest w pełni „zaktualizowana”. Tak więc dochodzimy do zagadnienia „wychowalności” osoby. Jest ona konsekwencją tego faktu, że rodzimy się wyposażeni w zadatki i właściwości będące jeszcze w stanie „embrionalnym”, to jest w stanie potencjalnym. Muszą one zostać rozwinięte u każdego - jeśli ma się stawać dojrzałą osobowością i każdy winien to czynić na miarę swych możliwości. 
Z tego co powiedziano wynika, że personalistyczna wizja człowie$\mathrm{ka}$, stanowiąca podstawę chrześcijańskiego wychowania, naprowadza nas przede wszystkim na ów pierwszy element tego, co człowiek przychodzący na świat zastaje jako niedoskonałe i w co od najwcześniejszego okresu życia ma wkraczać - a ma wkraczać we własne życie wewnętrzne: ma je „uprawiać”, to znaczy „kształtować człowieka w człowieku”, stawać się „coraz bardziej człowiekiem".

Aby mógł to czynić, potrzebuje pomocy określanej mianem wychowania. Dzięki tej pomocy będzie w stanie:

- poznawać całą, a nie cząstkową prawdę o sobie: kim jest i dokąd zmierza;

- poznawać prawdę o świecie i własnym w nim życiu oraz miejscu;

- poznawać prawdę o społeczeństwie i własnych wobec niego obowiązkach, a także przysługujących mu prawach;

- przygotować się do wolnego wyboru poznanych prawd i wartości;

- przygotować się do odpowiedzialnego podejmowania ról społecznych.

Ujmowanie wychowania jako ,uprawy człowieka” nasuwa dalszy jeszcze wątek. Nie tylko pedagog, ale każdy, kto zdroworozsądkowo patrzy na człowieka od jego najwcześniejszego okresu życia, jest świadom tego, że człowiek nigdy nie jest „,istotą gotową” - jest natomiast istotą ,ciagle się realizującą". Jego właściwym stanem jest nieustanne doskonalenie się: zmierzanie do własnej pełni. My, ludzie wierzący, powiemy: nieustanne „bycie w drodze". Każde zatrzymanie się jest równoznaczne ze schodzeniem z drogi, z opóźnianiem osiagnięcia celu, z samoumniejszaniem, czy nawet regresem. Pedagogom i duszpasterzom wiadomo, że punktem wyjścia owego doskonalenia jest człowiek, który jest. Punktem natomiast dochodzenia jest człowiek, który ma być. Jak trafnie to zauważa A. Gehlen, człowiek w punkcie wyjścia swego doskonalenia się to człowiek w swoich potrzebach - to jest rzeczywistość dana. Człowiek natomiast w punkcie dojścia, to człowiek w swoim ideale - to rzeczywistość zadana. Tą rzeczywistością „zadaną” jest właśnie „być bardziej człowiekiem”. Bycie „,złowiekiem” zawiera w sobie bogactwo treści: wyznaczają je sytuacje życiowe i oczekiwania konkretnych jednostek, względnie szerszego środowiska. Idzie tu bowiem o spełnienie określonych oczekiwań, pokładanie w kimś nadziei, liczenie na czyjąś dobroć, życzliwość, sprawiedliwość - łaskawość itp. Ale obok tego potocznego rozumienia ma ono w sobie coś głębszego, dla pedagogiki chrześcijańskiej samo przez się zrozumiałego: oznacza bowiem prowadzić życie wewnętrzne. Jak wiadomo, pojęcie życia wewnętrznego rozumie się często w znaczeniu bardziej szerokim: dla niektórych oznacza ono bogaty i różnorodny świat wartości, poszukiwań, pragnień, doznań i przeżyć. Dla pedagogiki chrześcijańskiej pojęcie to zawiera w sobie dalszą jeszcze treść, obejmowa- 
ną słowem duchowość. Tę natomiast można określić jako ukształtowanie się dojrzałej osobowości: w języku religijnym będzie to nazwane zmierzaniem do świętości, a w języku świeckim zmierzaniem ku pełni człowieczeństwa, pełni bycia soba.

Sobór Watykański II - kierując swe przesłanie do wszystkich ludzi podkreśla, że każdy człowiek jest powołany do prowadzenia życia wewnętrznego, to znaczy: rozwijania umysłu, kształtowania woli, harmonizowania swych duchowych władz, rozwijania w sobie uczuć społecznych i prowadzenia walki ze złem w oparciu o prawe sumienie. W nawiązaniu do tego przesłania można zatem w sumie powiedzieć, że „uprawa człowieka”, doskonalenie się, prowadzenie życia wewnętrznego - czyli „bycie człowiekiem” - oznacza z punktu widzenia wychowania chrześcijańskiego: stawać się coraz bardziej „bogatym w wartości duchowe i święte”. To znaczy wartości umożliwiające przekraczanie granic doczesności i sięganie ku Transcendencji.

W świetle powyższego niejako samorzutnie nasuwa się odpowiedź na pytanie o treść pojęcia „,pedagogika chrześcijańska” i „wychowanie chrześcijańskie". Oznacza ono kształtowanie osoby ludzkiej w kierunku jej celu ostatecznego, a równocześnie dla dobra społeczności, w których żyje i z których dorobku korzysta. Dokonuje się ono przez harmonijny rozwój wrodzonych właściwości fizycznych, intelektualnych i moralnych. W tym kształtowaniu osoby, będącej podmiotem dokonującego się procesu, niezbędna jest, ale wyłącznie jako pomocnicza, rola wychowawcy. Polega ona na udostępnianiu, przybliżaniu podmiotowi (posiadającemu swą autonomię) szeregu wartości stanowiących trwały dorobek społeczności i wyzwalających w podmiocie potencjalności wychowawcze. Idzie tu w sumie o stwarzanie korzystnych warunków te potencjalności wyzwalających i zabezpieczających wychowanka przed wyborem pseudowartości. Sam natomiast rozwój, doskonalenie osoby wychowanka jest i musi być jej dziełem: owocem jej wysiłków. Wobec przekazywanych wartości wychowanek musi mieć stosunek aktywny: musi je tak ,przepracować”, aby stały się jego własnością, wzbogacały go wewnętrznie, czyniły go zdolnym do wyboru dobra i jego współtworzenia.

Z powyższego wynika, że wychowanie oparte na personalistycznej wizji osoby jest wychowaniem do wolności: do wolności wyboru dobra. Wolność jest tu bowiem rozumiana nie jako swawola, niezdolność do przyjmowania jakichkolwiek zobowiązań, lecz jako zdolność wyboru dobra i jego realizacji: ustawicznego poszukiwania tego, co zostało poznane i uznane jako godne naszego dążenia - bowiem stanowi środek naszego doskonalenia osobowego.

Ów przymiot wolności w interesującej nas tu wizji człowieka-osoby ludzkiej, wyznacza kształt samego procesu wychowania. Wychowanie na- 
prawdę ludzkie zakłada bowiem wolność osoby, a ona oznaczać może zarówno przyjmowanie, podatność podmiotu wychowania na wychowawcze treści, jako też jej obojętność, względnie bierność czy nawet zdecydowany wobec nich sprzeciw. Taka sytuacja rodzi szczególne wymagania wobec nauczyciela-wychowawcy, jego kwalifikacji. Dobry nauczyciel wychowawca to ten, który potrafi doprowadzić do wewnętrznej zmiany u wychowanka. W wychowaniu chrześcijańskim oznaczać to będzie: odtworzyć w nim obraz dziecka Bożego - co św. Paweł wyraził w zdaniu „aż się Chrystus w nas ukształtuje". A w praktyce oznacza to budowanie wewnętrznego ładu u wychowanka, harmonii z Bogiem, ludźmi i sobą.

\section{Wychowanie chrześcijańskie w społeczeństwie wyboru}

Na kształt współczesnego wychowania wpływa w niemałym stopniu także i ta okoliczność, że dokonuje się w społeczeństwie określanym społeczeństwem wyboru, w przeciwieństwie do społeczeństwa tradycyjnego nazywanego społeczeństwem losu. Było to społeczeństwo wyrastające z tradycji, osadzone na niezmiennych wartościach moralnych, w wielu aspektach homogeniczne. Społeczeństwo pluralistyczne natomiast przedstawia swym członkom szerokie możliwości wyboru, których wachlarz ustawicznie się poszerza. Podsycane są też głoszoną ideą zmiany w każdej niemalże sferze życia - włącznie z religią i moralnością. Oferty zmiany charakteryzowane są jako wzbogacające i wyzwalające - a nierzadko odczuwane są jako „obciążenie" niemal nie do zniesienia. Cechą znamienną tych wyborów jest to, że są zewnętrznym wyrazem idei indywidualistycznych, dokonują się według indywidualnych opcji i są wolne od instytucjonalnych nacisków, tradycji i moralności zasadzającej się na religii.

Z wychowawczego i moralnego punktu widzenia na szczególną uwagę zasługuje to, że wśród różnych czynników na naczelne miejsce w dokonywaniu wyborów wysuwa się indywidualizm. Stanowi on wyraz, a zarazem jest konsekwencją pluralizmu. Charakteryzuje się tym, że ludzie na własną rękę usiłują określać swe preferencje życiowe i do nich dostosowywać normy moralne. Tu sam pojedynczy człowiek - a nie znajdujące się poza nim, czy ponad nim, siły zewnętrzne - niezależnie od tego, czy to są normy prawne, religijne, nacisk opinii środowiska rodzinnego czy oddziaływanie szkoły staje się ostateczną instancją legitymująca jego życiowe wybory i stosowane środki ich realizacji. Przyzwolenie społeczne na indywidualny - wolny wybór norm i środków realizacji dążeń życiowych jest rozumiane niejako jako „konieczność” społeczeństwa pluralistycznego. Tą drogą rozpada się zintegrowany system społeczno-moralny: orientacja na wartości uniwersalne 
(uznawane do niedawna przez całe społeczeństwo) wypiera nastawienie na wartości definiowane indywidualistycznie i sytuacyjnie. Ów pluralizm wartości jako regulator życia jednostkowego i społecznego - owocujący w indywidualnych, wolnych wyborach - wynika głównie z zakwestionowania tezy o istnieniu jednej, obiektywnej prawdy. Zgodnie bowiem z pluralistycznym sposobem myślenia uznanie jednej obiektywnej prawdy oznaczałoby hołdowanie przymusowi i represywności - to znaczy totalitaryzmowi.

Z oczywistych względów ów „pluralistyczny sposób myślenia” stoi w sprzeczności z podstawowymi założeniami pedagogiki chrześcijańskiej. Pyta mianowicie o konsekwencje wychowawcze tak ukształtowanego pluralizmu; rozbicie jednolitego systemu wartości i norm jednostkowych i społecznych oznacza, że społeczeństwo przestaje być „całością moralną" rządzącą się wspólnie obowiązującymi normami. Dzieje się tak dlatego, że pluralizm strukturalno-aksjologiczny występujący w mikroskali (indywidualne wybory) łatwo przesuwa się na płaszczyznę makrospołeczną. $\mathrm{Z}$ bogatego „rynku wartości” coraz szersze rzesze coraz chętniej biorą to, co łatwe, atrakcyjne, a zwłaszcza niewymagające wyrzeczeń.

W dalszej kolejności i konsekwencji w oczywisty sposób prowadzi to do wytworzenia się próżni aksjologicznej, której cechą znamienną jest to, że dla poszczególnego, konkretnego człowieka nic nie jest oczywiste: nie ma bowiem jednolitego punktu odniesienia. Każda sytuacja - i to zarówno w swym wymiarze indywidualnym, jak i społecznym - może być oceniana, wartościowana z różnej perspektywy. A stąd - jak wiadomo - prowadzi droga do nieuniknionego relatywizmu moralnego: dla koherencyjnego systemu wartości i norm, który scalałby społeczeństwo i wyznaczał sposoby działania, nie ma tu już miejsca.

Wzory ocen siebie $\mathrm{i}$ innych oraz wzory działań opierają się najchętniej na „zasadzie przyjemności” oraz wolności wyborów między przyjemnościami płynącymi z używania. Przyjemność daje konsumpcja - i to konsumpcja wszystkiego. „Nie życie lecz użycie” staje się dominującym stylem myślenia i działania. Życie jest traktowane jako rodzaj zabawy: rodzi chęć korzystania z każdej nadarzającej się przyjemności. Badacze tego zagadnienia mówią nawet o „konsumpcji rozrywki i zabawy” jako kulturowym wzorze życia społeczeństwa aksjologicznego pluralizmu. Ma tu miejsce pełna redukcja człowieka do wymiarów doczesności.

Tymczasem, dla funkcjonowania zintegrowanego moralnie i kulturowo społeczeństwa - zarówno w makro, jak i mikro sakli - niezbędne są ogólnie obowiązujące, zinstytucjonalizowane normy i wzory zachowań przekazywane z pokolenia na pokolenie, a dotyczące szczególnie ważnych dla społeczeństwa sfer życia, które nie mogą być ujmowane w kategoriach zabawy. Wchodzi tu niewątpliwie w grę: przekazywanie życia w ramach instytucji 
małżeństwa i rodziny, samorealizowanie się seksualne jako mężczyzna i kobieta, poszanowanie życia od chwili jego poczęcia aż do chwili śmierci, socjalizacja w ramach instytucji kształcenia i wychowania, życie w społeczeństwie zorganizowanym i ustrukturyzowanym. Zinstytucjonalizowane normy i wzory zachowań nadają społeczny kształt życia ludzkich zbiorowości, utrwalają jego struktury zewnętrzne oraz pełnią funkcję kontroli zachowań jednostkowych i zbiorowych - wyznaczając granice między zachowaniami pożądanymi i dewiacyjnymi oraz określając dopuszczalne alternatywne formy zachowań.

Pozostaje wreszcie - gdy mowa o wychowaniu dla społeczeństwa pluralistycznego - wspomniany wyżej problem ,wielości prawdy”. Sądzę, że bezdyskusyjnie należałoby się zgodzić co do tego, że niezależnie od wysuwanych w tym zakresie roszczeń i głoszenia wielu „prawd” przez różne opcje filozoficzno-światopoglądowe, aksjologiczne i polityczne, bynajmniej nie może wchodzić w grę konieczność rezygnacji z absolutnej prawdy. Z tego, że ludzie wyznają różne hierarchie wartości i uznają różne „prawdy”, nie wynika, że prawda i wartości mają względny charakter; z tego, że liczni hołdują wzorom zachowań niezgodnym $\mathrm{z}$ uświęconymi tradycją społeczno-moralną standardami nie wynika, że należy to uznać za normalne i kulturowo zaakceptować - może to być jedynie w dopuszczalnych granicach tolerowane. Tak jak oczywiste jest, że pluralizm kulturowy wymaga uznania wielości opinii, stanowisk, mieszczących się w określonych granicach zachowań, tak też oczywiste jest, że nie wszystkie stanowiska są jednakowo prawomocne, i że człowiek może poznać Prawdę Absolutną - zbliżać się do niej. W przeciwnym bowiem przypadku zamazywałyby się granice między dobrem a złem, prawdą i kłamstwem. Uznanie pluralizmu za istotną cechę współczesnego społeczeństwa i kultury nie musi automatycznie oznaczać aprobaty dla wszystkich zachowań i wzajemnie wykluczających się poglądów: nie można jednocześnie aprobować dobra i zła, moralności i niemoralności, prawdy i fałszu. Nie ma potrzeby dowodzenia, że istnieje prawda i kłamstwo, wartości i antywartości, normy niekwestionowane, i że to one tkwią w każdej zdrowej kulturze, a wierność im stanowi o autentycznie ludzkim wymiarze kultury i zdrowym moralnie społeczeństwie.

A zatem, jak każde zdrowe społeczeństwo, tak też społeczeństwo pluralistyczne nie może być pozbawione fundamentu nienaruszalnych wartości - wartości uniwersalnych. One stanowią konieczny warunek rozwoju osoby ludzkiej i prawdziwie ludzkiej kultury. Pluralizm może być bowiem wyrazem i podstawą bogactwa i zdrowia danej kultury, ale może też być źródłem dezintegracji kultury, jej rozpadu, utraty jej tożsamości. Dlatego też w wychowaniu chrześcijańskim wyznacza się mu dopuszczalne ramy i granice, a nie neguje. 
Z tego, co powiedziano, wynika, że rzeczywistość społeczno-kulturowa charakteryzowana mianem pluralistycznej nie może być pozbawiona fundamentu wartości nienaruszalnych; w przeciwnym razie demokracja przekształca się w dyktaturę - podstawową regułą życia społecznego i źródłem moralności będzie dyktat mocniejszych nad słabszymi, przemocy nad prawem, a pluralizm przekształci się $\mathrm{w}$ anarchizm. Jest bezdyskusyjne, że Polska - i nie tylko Polska - edukacja stoi przed niekwestionowaną potrzeba budowania zdrowego programu wychowania do pluralizmu społeczno-kulturowego, to znaczy programu opartego na akcentowanych tu wartościach humanistycznych i chrześcijańskich - na których została zbudowana cywilizacja i kultura europejska. Należą do nich - jak wiadomo - prawda o człowieku i jego miejscu w świecie i społeczeństwie, wolność i odpowiedzialność, prawo do „bycia sobą” - zakładające „bycie z drugimi”, a nie „obok drugich", tolerancja - określona granicami uprawnień drugiego człowieka i wymogów integracji całej społeczności.

Wychowanie to musi być prowadzone-realizowane na dwóch płaszczyznach:

- na płaszczyźnie kształtowania postaw; sięgając do duchowego wnętrza człowieka i uświęconych norm społeczno-moralnych;

- na płaszczyźnie struktur; dla uzdrawiania organizmu społecznego zdeprawowanego w minionym okresie i deformowanego współcześnie pod wpływem ideologii opacznie pojmowanego pluralizmu społeczno-kulturowego i aksjologicznego.

Ów pierwszy poziom wyznacza stojące przed edukacją - na szeroką skalę zaniedbywane, a przypomniane przez Papieża w czerwcu 1997 roku w Skoczowie - zadanie wychowania sumienia. Dokonuje się ono dzięki wychowującym moralnie treściom każdego nauczanego przedmiotu i osobistemu świadectwu nauczyciela. Wychowanie sumienia nie może być wciąż traktowane jako zadanie należące do rodziny i katechizacji. Przezwyciężanie moralnego relatywizmu, osadzonego na subiektywnej opcji i wyłączającego niezmienne prawa moralne i wzory zachowań, jest możliwe tylko poprzez wychowanie prawego sumienia. Wychowanie natomiast prawego sumienia niezbędnie zakłada „odzyskanie powszechnej świadomości prymatu wartości moralnych, które są wartościami osoby ludzkiej jako takiej” (VS 101).

To właśnie prymat wartości moralnych, jako wartości osoby ludzkiej, stanowi niekwestionowany warunek budowy zdrowych moralnie struktur ekonomiczno-ustrojowych i edukacyjnych społeczeństwa pluralistycznego. W praktyce oznacza to nic innego, jak przywracanie ustawiczne należnej rangi wartościom leżącym u podstaw kultury europejskiej, której kształt wyznaczało chrześcijaństwo: jako idea życia społecznego budowanego na personalistycznej wizji człowieka-osoby w jego integralnym wymiarze. 
Niewątpliwie kultura współczesnego świata i oparta na niej edukacja zostały - jak nigdy dotąd - dotknięte poważnymi wypaczeniami i z tej przyczyny przeżywają głęboki kryzys, którego istotą jest zagrożenie osobowego wymiaru człowieka. Najistotniejszym z tych zagrożeń jest alienacja - polegająca na tym, że wytworzone przez człowieka rzeczy, narzędzia, urządzenia społeczne i ustroje polityczne osiagnęły niezależny od niego byt i często skierowują się przeciw niemu: stanowiąc dlań zagrożenie biologiczne, psychiczne i moralne. Niejako w parze z poprzednim, a w interesującym nas tu zakresie rozważań, nie mniejszym zagrożeniem jest upowszechnianie się postawy dominacji „mieć” nad „być”: czego konsekwencją jest to, że człowiek staje się rzeczą wśród rzeczy; zatraca swój podmiotowy charakter bytu ludzkiego, w coraz szerszym zakresie nastawia się na konsumpcyjny styl życia. Nie można wreszcie pominąć zagrożenia, jakim jest deformacja niezbywalnego przymiotu osoby ludzkiej - wolności, pojmowanej jako „wolność od": od wszelkich ograniczeń i zobowiązań, łącznie z tymi, których domaga się natura i jej prawa.

Kultura współczesnego świata, zamiast pomagać człowiekowi w stawaniu się „coraz bardziej człowiekiem”, stała się tego stawania bariera, niejednokrotnie barierą nader trudną do pokonania. $Z$ tej też przyczyny warto zwrócić się w kierunku integralnej wizji człowieka leżącej u podstaw chrześcijańskiej-personalistycznej pedagogiki.

\section{Christian Pedagogy as a Personalistic Pedagogy (Summary)}

The paper evaluates the specific character of Christian pedagogy. In order to do that, the author firstly characterizes example trends and direction in pedagogy; secular, radical-emancipation, technological-functional, Waldorf education, humanistic education and antipedagogy. The profile of Christian educational philosophy is revealed on its background. The author characterizes it, starting off with anthropological fundaments, created by Thomas Aquinas and Augustine of Hippo, as well as those which find its full development in personalistic philosophy. Presenting the anthropological personalistic philosophy, the author indicates key consequences brought by it in the field of pedagogy. Own considerations are supplemented by reference to documents of Church. The last part of the article tries to present how Christian upbringing operates in the society of choice developed on the turn of the century.

Keywords: Christian pedagogy; personalism; anthropology; society of choice. 


\section{Pedagogika chrześcijańska pedagogiką personalistyczną (Streszczenie)}

Artykuł przybliża specyfikę pedagogiki chrześcijańskiej. W tym celu autor charakteryzuje najpierw przykładowe nurty i kierunki w pedagogice: laicki, radykalno-emancypacyjny, technologiczno-funkcjonalny, pedagogikę steinerowską, humanistyczną, antypedagogikę. Na ich tle uwidacznia się profil chrześcijańskiej myśli pedagogicznej. Autor charakteryzuje jac wychodząc od fundamentów antropologicznych, tworzonych przez Augustyna i Tomasza z Akwinu, oraz znajdujących pełne rozwinięcie w myśli personalistycznej. Prezentując personalistyczną myśl antropologiczną, autor wskazuje na podstawowe konsekwencje, jakie przynosi ona w dziedzinie pedagogiki. Swoje rozważania uzupełnia również poprzez odwołanie do dokumentów Kościoła. Ostatnia część artykułu jest próbą ukazania, na czym polega wychowanie chrześcijańskie w społeczeństwie wyboru, jakie ukształtowało się na przełomie XX i XXI wieku.

Słowa kluczowe: pedagogika chrześcijańska; personalizm; antropologia; społeczeństwo wyboru. 